\title{
ENDOCRINE, LIFESTYLE, AND GENETIC FACTORS IN THE DEVELOPMENT OF METABOLIC SYNDROME
}

\author{
Zorana SLANOVIC-KUZMANOVIĆ, Ivan KOS, and Ana-Marija DOMIJAN \\ Faculty of Pharmacy and Biochemistry, University of Zagreb, Zagreb, Croatia \\ Received in November 2012 \\ CrossChecked in November 2012 \\ Accepted in October 2013
}

\begin{abstract}
Metabolic syndrome (MetS) is a chronic, multi-component disease characterised by central obesity, hyperglycaemia, dyslipidaemia, and hypertension. Since MetS leads to type 2 diabetes, cardiovascular disease, development of certain cancers, and eventually to premature death, it is not surprising that it draws the attention of scientists around the world. The aetiopathology of MetS is complex and still not fully understood. This review focuses on the role of endocrine factors such as cortisol and insulin in the development of MetS. It also takes a look at some of the contributing lifestyle and genetic factors as well as at the current knowledge about its treatment.
\end{abstract}

KEY WORDS: cardiovascular diseases, circadian rhythm, cortisol, hyperglycaemia, hypertension, insulin, Met $S$, type 2 diabetes

Metabolic syndrome (MetS) is a modern disease characterised by the clustering of abnormalities such as central obesity, high levels of fasting glucose and triglyceride, low levels of high-density lipoprotein (HDL), and hypertension $(1,2)$. The prevalence of MetS has been increasing over the past two decades (1), and recent studies (3-5) suggest that it has reached $25 \%$ among the adults worldwide. Reports vary from $21.9 \%$ in men and $16.8 \%$ in women in north-eastern Italy, and $24.6 \%$ in alcohol-dependent male patients in north India to $31.25 \%$ in rural women from Bangladesh. A small study on salt intake with 92 participants in Croatia reports the prevalence of $31.5 \%$ (6). Among obese adolescents and pubertal children, the prevalence of MetS could be around $15 \%$, judging by the reports of $14 \%$ in Danish obese adolescents (7) and of $9.7 \%$ to $41.2 \%$ in obese pubertal children and $8.3 \%$ to $34.2 \%$ in obese prepubertal children in Spain (8). The latter study makes a point that the prevalence of MetS depends on criteria used. Organisations such as the World Health Organization (WHO) and the American Heart Association and the National Heart, Lung, and Blood Institute (AHA/NHLBI) differ in diagnostic criteria for MetS (Table 1) (9-12). It is also evident that the prevalence of MetS increases with age; Novalletto et al. (3) reported the prevalence of $29.8 \%$ in a group aged 60 to 69 years vs. $8.0 \%$ in a group aged 30 to 39. The aetiopathology of MetS is still unclear but is believed to be a combination of modern lifestyle, environmental factors, and heredity in some populations $(2,13)$. More importantly, patients diagnosed with MetS are at high risk of developing type 2 diabetes, cardiovascular disease, certain cancers, and of premature death (14-17).

The subtle interplay between MetS and hormones is well established. Adipose tissue, a hallmark of MetS, is not just inert reserve of fat, but an active endocrine 
organ that plays an important role in the secretion of insulin and other hormones which regulate energy metabolism (18). In turn, many hormones and their receptors have important roles in regulating food intake, energy expenditure, and neuro-endocrine output of the pituitary gland and may contribute to the accumulation of fat.

The aim of this article is to give an overview of some of the most important endocrine, lifestyle, and genetic factors that are involved in the development of MetS. It also presents current knowledge on MetS treatment.

\section{Endocrine factors and MetS}

Cortisol is a glucocorticoid hormone secreted by the adrenal gland and is regulated by the adrenocorticotropic hormone (ACTH), whose secretion is, in turn, regulated by vasopressin and corticotrophin-releasing hormones, released by the hypothalamus. This complex set of hormone interactions is referred to as hypothalamic-pituitaryadrenal (HPA) axis. Cortisol regulates energy metabolism through gluconeogenesis, but also affects processes such as inflammation $(19,20)$. Various cortisol-regulated physiological processes depend on glucocorticoid receptor (GR), which is activated upon cortisol binding $(20,21)$. On the pre-receptor level, cortisol action is additionally regulated by the intracellular enzyme $11 \beta$-hydroxysteroid dehydrogenase (11 $\beta$-HSD) $(20,22,23)$ that comes in

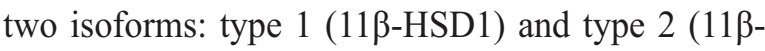
HSD2). Type 1 catalyses the conversion of the inactive form cortisone into active cortisol, while type 2 converts active cortisol into its inactive form cortisone to lower the levels of active glucocorticoid and to inhibit cortisol activity $(22,24)$. Therefore, the level of cortisol in a particular tissue depends on blood cortisol levels produced by the adrenal gland and on tissue activity of $11 \beta$-HSD1 and density of GR (Figure 1) $(20,21)$.

Higher cortisol levels in MetS patients suggest that cortisol contributes to the pathogenesis of MetS (22, $25)$. Studies conducted so far $(25,26)$ indicate that higher HPA axis activity and cortisol level are associated with central obesity, but the nature of this relationship remains ambiguous. Grossniklaus et al. (26) associated higher body mass index (BMI) and higher morning salivary cortisol levels in middle-aged women with greater waist circumference (WC). Park et al. (25) found that higher cortisol level in Korean men and women was associated with increased risk

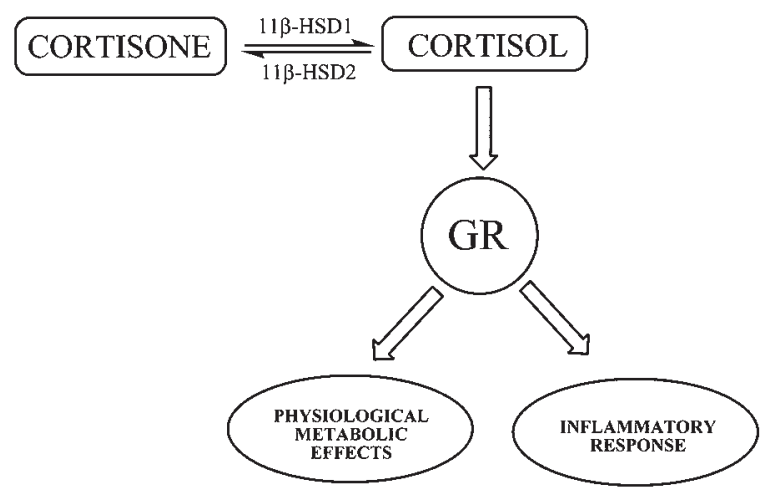

Figure 1 Intracellular action of cortisol depends on the conversion of cortisone to cortisol (and vice versa) by $11 \beta$-hidroxysteroid dehydrogenase (11 $\beta$-HSD) and on its binding to glucocorticoid receptor $(G R)$ (adapted from ref. 20). Isoform 11 $\beta$-HSD type 1 $(11 \beta$-HSD1) converts inert cortisone to receptoractive cortisol. Upon binding of cortisol to GR, GR is activated and can regulate the expression of genes involved in various physiological functions, including energy metabolism and inflammation.

of MetS, but since they found no association between cortisol and BMI or WC, the authors concluded that higher cortisol was associated with MetS regardless of overall adiposity. Mai et al. (27), however, observed a direct association between lipids and cortisol levels. They induced hyperlipidaemia in healthy young women of normal weight by treating them with $20 \%$ lipid/heparin infusion and found higher serum cortisol than in controls (who received saline/heparin infusion). The authors concluded that hyperlipidaemia may increase adrenal sensitivity to ACTH, leading to greater cortisol release, such as in patients with MetS. This effect might contribute to disturbances along the HPA axis found in women with central obesity and impaired lipid metabolism.

It is important to note that cortisol secretion also depends on age and sex. In a study with untreated volunteers, Velhuis et al. (28) observed that cortisol secretion increased with age, especially in men, and that cortisol-ACTH feedback synchrony and ACTHcortisol feedforward synchrony declined with age and, again, were more pronounced in men. In addition, they observed that pulsatile and basal ACTH secretion and mean ACTH concentrations all increased with BMI and were higher in men than women. In other words, BMI also contributed to cortisol secretion.

We have already mentioned that cortisol action depends on the GR density and the activity of $11 \beta$ HSD1 enzyme. According to a number of reports (19, $22,25)$ the visceral adipose tissue stores more GR than other fat depots and shows greater expression of $11 \beta$ - 
HSD1 in obese subjects $(29,30)$. Together with excess glucocorticoid secretion by the HPA axis (through increased peripheral glucocorticoidal signalling and cortisol reactivation) this may contribute to higher cortisol level observed in MetS.

Centrally distributed fat or central obesity is characteristic of MetS, and adipose tissue not only stores fat but works as an endocrine organ, as it produces pro-inflammatory cytokines (adipokines) such as tumour necrosis factor $\alpha(\mathrm{TNF} \alpha)$ and interleukin-6 (IL-6) $(1,23)$. In other terms, MetS is a state of chronic, low-grade inflammation (23). How does this explain the involvement of cortisol? Cortisol is released to stop tissue destruction and autoimmune processes. Classen (31) has reported that iatrogenic inflammation activates immunosuppressive cortisol response, which protects against type 1 diabetes and other autoimmune diseases, but causes type 2 diabetes, MetS, and obesity. Persistently high cortisol levels cause a number of adverse reactions, as they disrupt normal physiological functions. On the one hand, cortisol induces excessive glucose release from the liver, insulin resistance, free fatty acid release from adipocytes, and hypertension. On the other, it may chronically suppress immune reactions and anabolic processes in muscles. These changes increase the risk of MetS and other diseases such as morbid obesity, type 2 diabetes, infections, or endocrine disorders.

Fasting hyperglycaemia and/or insulin resistance and compensatory hyperinsulinaemia are the most important symptoms of MetS. Insulin resistance is the inability of insulin to act even though its secretion from $\beta$-cells is normal (18). In addition to its important role in energy metabolism, insulin affects cell growth and differentiation, as well as endothelial function. It is probably because of this variety of insulin action that MetS is able to affect it. For one, cortisol can interfere with insulin action by stimulating excessive hepatic gluconeogenesis, by inhibiting glycogen synthase in the muscles, and by promoting lypolisis in the adipose tissue $(19,22,32)$. For two, central obesity can affect insulin action, as adipose tissue releases TNF- $\alpha$, IL- 6 , and free fatty acids, which block normal insulin signalling pathway $(2,18)$. In addition, adiposity is characterised by low levels of adiponectin (a tissue-specific circulating adipokine with insulinsensitising and anti-atherogenic properties), which contributes to systematic insulin resistance $(18,15$,

Table 1 Criteria for diagnosing the metabolic syndrome proposed by different organisations

\begin{tabular}{|c|c|c|c|c|}
\hline PARAMETER & $\mathrm{WHO}^{\mathrm{a}}$ & AHA/NHLBI ${ }^{b}$ & IDF $^{\mathrm{c}}$ & EGIR $^{d}$ \\
\hline $\begin{array}{l}\text { Obesity (as } \mathrm{WHR}^{\mathrm{e}} \text {, } \\
\mathrm{WC}^{\mathrm{f}} \text { or } \mathrm{BMI}^{\mathrm{g}} \text { ) }\end{array}$ & $\begin{array}{c}\text { WHR }>0.9(\mathrm{~m}) ; \\
\text { WHR }>0.85(\mathrm{w}) ; \text { or } \\
\quad \text { BMI }>30 \mathrm{~kg} \mathrm{~m}^{-2}\end{array}$ & $\begin{array}{c}\mathrm{WC} \geq 102 \mathrm{~cm}(\mathrm{~m}) ; \\
\mathrm{WC} \geq 88 \mathrm{~cm}(\mathrm{w}) \\
\text { (ethnic values for } \mathrm{WC} \\
\text { recommended) }\end{array}$ & $\begin{array}{c}\mathrm{WC} \geq 94 \mathrm{~cm}(\mathrm{~m}) ; \\
\mathrm{WC} \geq 80 \mathrm{~cm}(\mathrm{w}) ; \text { or } \\
\mathrm{BMI}>30 \mathrm{~kg} \mathrm{~m}^{-2}\end{array}$ & $\begin{array}{l}\mathrm{WC} \geq 94 \mathrm{~cm}(\mathrm{~m}) \\
\mathrm{WC} \geq 80 \mathrm{~cm}(\mathrm{w})\end{array}$ \\
\hline Fasting glucose & $\begin{array}{c}\geq 6.1 \mathrm{mmol} \mathrm{L}^{-1} \text { and } / \text { or } \\
\text { impaired glucose } \\
\text { tolerance }\end{array}$ & $\begin{array}{l}\geq 5.6 \mathrm{mmol} \mathrm{L}^{-1} \text { or on } \\
\text { therapy }\end{array}$ & $\geq 5.6 \mathrm{mmol} \mathrm{L}^{-1}$ or $\mathrm{DM}$ & $\begin{array}{l}\geq 6.1 \mathrm{mmol} \mathrm{L}^{-1} \\
\text { without DM }\end{array}$ \\
\hline Blood pressure & $\geq 140 / 90 \mathrm{~mm} \mathrm{Hg}$ & $\begin{array}{c}\geq 130 / 85 \mathrm{~mm} \mathrm{Hg} \text { or } \\
\text { on therapy }\end{array}$ & $\begin{array}{c}>130 / 85 \mathrm{~mm} \mathrm{Hg} \text { or } \\
\text { on therapy }\end{array}$ & $\begin{array}{c}\geq 140 / 90 \mathrm{~mm} \mathrm{Hg} \text { or } \\
\text { on therapy }\end{array}$ \\
\hline HDL cholesterol & $\begin{array}{l}<0.9 \mathrm{mmol} \mathrm{L}^{-1}(\mathrm{~m}) \\
<1 \mathrm{mmol} \mathrm{L}^{-1}(\mathrm{w})\end{array}$ & $\begin{array}{l}<1.03 \mathrm{mmol} \mathrm{L}^{-1}(\mathrm{~m}) \\
<1.3 \mathrm{mmol} \mathrm{L}^{-1}(\mathrm{w}) ; \text { or } \\
\text { on therapy }\end{array}$ & $\begin{array}{l}<1.03 \mathrm{mmol} \mathrm{L}^{-1}(\mathrm{~m}) ; \\
<1.29 \mathrm{mmol} \mathrm{L}^{-1}(\mathrm{w}) ; \\
\quad \text { or on therapy }\end{array}$ & $\begin{array}{c}<1 \mathrm{mmol} \mathrm{L}^{-1} \text { or on } \\
\text { therapy }\end{array}$ \\
\hline Triglycerides & $\geq 1.7 \mathrm{mmol} \mathrm{L}^{-1}$ & $\begin{array}{c}\geq 1.7 \mathrm{mmol} \mathrm{L}^{-1} \text { or on } \\
\text { therapy }\end{array}$ & $\begin{array}{c}\geq 1.7 \mathrm{mmol} \mathrm{L}^{-1} \text { or on } \\
\text { therapy }\end{array}$ & $\begin{array}{c}>2 \mathrm{mmol} \mathrm{L}^{-1} \text { or on } \\
\text { therapy }\end{array}$ \\
\hline Microalbuminuria & 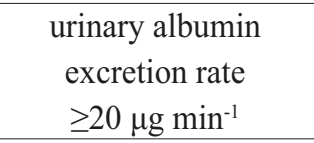 & l & / & l \\
\hline $\begin{array}{l}\text { Requirements for } \\
\text { diagnosing MetS }\end{array}$ & $\begin{array}{l}\geq 2 \text { of any }+ \text { insulin } \\
\text { resistance and/or DM }\end{array}$ & $\geq 3$ of any criteria & $\begin{array}{c}\geq 2 \text { of any }+ \text { obesity } \\
\text { (with ethnicity } \\
\text { specific values) }\end{array}$ & $\begin{array}{c}\geq 2 \text { of any }+ \text { insulin } \\
\text { resistance }\end{array}$ \\
\hline
\end{tabular}


23). Long-term elevation of insulin levels causes desensitisation of insulin receptors, which in turn may lead to hyperglycaemia, smooth muscle hypertrophy, hypertension and many other physiological disorders (33).

One way in which hyperinsulinaemia leads to hypertension is by overstimulating the sympathetic nervous system through increased plasma noradrenaline levels, heart rate, renal sodium re-absorption, cardiac output, and peripheral resistance (34). There are several other mechanisms (such as the reninangiotensin-aldosterone system, mitogen-activated protein kinase pathway, increased levels of free fatty acids, and pro-inflammatory cytokines through which MetS (via insulin resistance and obesity) increases blood pressure (for review see 33).

\section{Lifestyle factors and MetS}

The release of hormones, including cortisol, follows a daily pattern we usually refer to as circadian rhythm. Normally, cortisol peaks in the early morning, keeps falling for the rest of the day, and troughs around midnight, only to rise quickly over the second half of the night (Figure 2). These circadian oscillations are controlled by the suprachiasmatic nucleus ( $\mathrm{SCN}$ ), a cluster of neurons in the hypothalamus, but also by peripheral oscillators that exist in most tissues of the body $(35,36)$. The internal biological clock is primarily aligned with the light/dark cycle, but is also affected by other factors such as locomotor activity and food intake (35-37). The circadian clock controls nearly all of the physiological and behavioural events in the body $(36,37)$. Any chronic misalignment between circadian rhythm and sleep or feeding can therefore lead to adverse metabolic and cardiovascular changes $(38,39)$. Modern lifestyle seems to be an epitome of this misalignment, as it usually implies physical inactivity, smoking, alcohol consumption, untimely feeding, and exposure to bright light over night. All these factors greatly contribute to the development of MetS. Here we shall focus on shift work, sleep deprivation, and stress.

Shift work can greatly disturb the circadian and behavioural rhythm and contribute to the development of obesity, diabetes, and cardiovascular disease. In a 10-year follow-up study, Morikawa et al. (40) established a clear association between shift work and BMI (the highest increase in BMI was found in workers who transferred from daytime work to shift work). In another retrospective longitudinal study (41) covering the period between 1976 and 2007, night

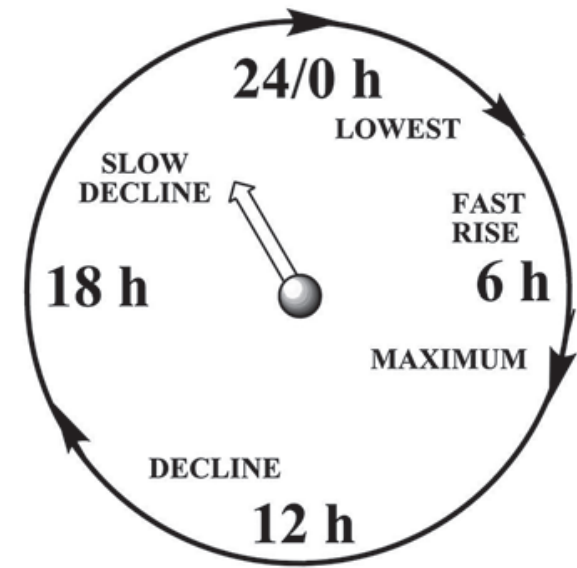

Figure 2 Circadian rhythm of cortisol

workers demonstrated not only significantly higher BMI, but also serum total cholesterol, triglycerides, and incidence of coronary heart disease than day workers. In yet another study, Manenschijn et al. (42) established higher BMI in shift workers and its correlation with higher cortisol levels in scalp hair and cardiovascular risk. Assessing several metabolic and endocrine parameters, Scheer at al. (38) found that experimental short-term circadian misalignment (similar to acute jet lag or chronic shift work) resulted in lower leptin, higher glucose, insulin, and mean arterial pressure, reduced sleep efficiency, and complete inversion of the cortisol behaviour across the circadian cycle. The authors conclude that a change in any of these parameters can trigger underlying mechanisms for MetS and cardiovascular disease. Cases in point, they argue, are the inversion of cortisol behaviour that can lead to insulin resistance and hyperglycaemia and lower leptin that can stimulate appetite and diminish energy expenditure.

Prolonged sleep deprivation is another predisposing factor for obesity, type 2 diabetes, and cardiovascular disease. In an eight-year follow-up study by Gangwisch et al. (43), short sleep (less than five hours a night) was associated with a significantly increased risk of hypertension. Since blood pressure drops $10 \%$ to $20 \%$ in normotensive subjects during sleep, the authors concluded that the reason was the prolonged cycle of higher blood pressure, heart rate, sympathetic nervous system activity, physical and psychosocial stress, and increased salt retention associated with wakefulness. Vgontzas et al. (44) found a strong inverse correlation between sleep deprivation and WC. Several studies have shown that depriving healthy subjects of sleep can raise glucose and cortisol levels, 
lower insulin sensitivity and leptin levels, and increase appetite (37). Kumari et al. (45) found that short sleep and sleep disturbances were independently associated with greater cortisol release, especially in the evening, which points to the deregulation of the feedback in the HPA axis. However, the specific mechanisms and the involvement of the sympathetic nervous system and HPA axis remain to be elucidated.

Stress disorders such as depression and posttraumatic stress disorder (PTSD) have also been associated with metabolic abnormalities, including obesity, dyslipidaemia, high blood pressure, and insulin resistance. Paslakis et al. (46) found that $42.1 \%$ of patients with major depression met the criteria for MetS diagnosis. Vogelzangs et al. (47) showed that depression led to increased visceral fat, independent of overall obesity. The same group of authors observed a synergistic relationship between depression, cortisol, and MetS and concluded that depression and high cortisol increase the odds for MetS (48). However, the association between depression and MetS could be a two-way street, that is, it could be MetS that leads to depression and not the other way around (49). Capuron et al. (50) claim that chronic low-grade inflammation pertinent to MetS can contribute to mood alterations. These findings raise the question whether the treatment of depression would positively reflect on MetS and vice versa, whether the treatment of MetS would relieve depression. Preliminary evidence suggests that antidepressant therapy (a four-week treatment with reboxetine) can have beneficial effects on several metabolic parameters, independent of treatment outcome, that can be attributed to the pharmacological profile of the drug (46). Vogelzangs et al. (51) showed that antidepressants act differently on inflammation. Tricyclic antidepressants, tetracyclic antidepressants, and serotonin-norepinephrine reuptake inhibitors stimulated inflammation level, whereas selective serotonin reuptake inhibitors inhibited it. Rege (52) demonstrated that first (chlorpromazine, zuclopenthixol, haloperidol, and trifloperazine) and second-generation antipsyhotics (clozapine, olanzapinme, risperidone, paliperidone, and quetiapine) stimulated gain weight. Weight gain can be a result of reduced resting energy expenditure. Blocking the histamine $\mathrm{H} 1$ receptor increases appetite, while serotonin $2 \mathrm{C}\left(2-\mathrm{HT}_{2 \mathrm{C}}\right)$ interaction with antipsychotics stimulates food intake despite satiety (53-55). A recent study (56) confirmed that users of tricyclic antidepressants were prone to obesity and dyslipidaemia and it associated low-grade inflammation with more severe anxiety disorders and depression.

\section{Genetic factors and MetS}

The central rhythm generator in mammals, SCN, receives light information from the retinal photoreceptor cells and transmits them as neuronal and/or humoral signals through the body (36). To keep this rhythm regular, the SCN needs Clock genes, which make up an auto-regulatory feedback loop by interacting with each other and generate circadian rhythms at the molecular level $(36,37,57)$. Clock genes are expressed not only in the SCN and other locations in the brain, but also in the liver, heart, skeletal muscle, adipose tissue, and adrenal glands $(35,58)$. Peripheral Clock genes have their own intrinsic oscillatory systems that are regulated by the $\operatorname{SCN}(36,59)$. However, peripheral clocks are capable of sustaining circadian rhythms even in the absence of SCN input and may therefore play an important role in regulating peripheral circadian rhythms of physiological processes $(36,37)$. Valenzuela et al. (59) found oscillatory expressions of Clock genes Per2 and Bmall in adrenal explants of an adult capuchin monkey, demonstrating that the primate adrenal gland has intrinsic capacity to maintain Clock gene oscillation. Also in that study, adrenal Clock gene expression was directly affected by the neurohormone melatonin, further confirming the independence of peripheral clocks. GomezAbellan et al. (60) demonstrated Clock genes in human adipose tissue and their association with MetS. In the next study (61), the same authors confirmed that peripheral Clock genes (hPer2, hBmall, and hCryl) in explants of adipose tissue in morbidly obese women oscillated accurately and independently of the SCN. They also observed that peripheral Clock genes controlled the timing of GR and 11 $\beta$-HSD1 genes, and that this intracellular circadian clock could independently regulate peripheral cell functions.

We have mentioned earlier that the expression of the enzyme $11 \beta-H S D 1$ is higher in the adipose tissue of obese subjects and that it increases the risk of obesity and MetS (22, 23). Gambinieri et al. (62) established a correlation between single nucleotide polymorphisms (SNPs) of HSD11B1, the gene encoding for enzyme 11 $\beta$-HSD1, and type 2 diabetes, hypertension, and hyperandrogenism in women with the polycystic ovary syndrome (POCS). They studied two common SNPs (rs846910 and rs12086634) in HSDI1B1 in a population of Southern European Caucasian women with and without PCOS and found 
that regardless of PCOS, HSD $11 B 1$ alleles containing rs846910 A and rs12086634 T increased 11 $\beta-H S D 1$ expression and activity (observed in higher 11 $\beta$-HSD1 mRNA levels in the adipose tissue and higher rates of appearance of an active cortisol during cortisol steadystate infusion). To establish tissue-specific cortisol profile in morbidly obese patients, Torrecilla et al. (63) investigated the mRNA expression of genes related to peripheral cortisol activity, including those coding for $11 \beta$-HSD1, hexose-6-phosphate dehydrogenase (H6PDH), GR, and phosphoenolpyruvate carboxykinase (PEPCK) in the liver, visceral, and subcutaneous adipose tissues in morbidly obese patients with and without MetS. In the liver, mRNA expression of the tested genes was higher in patients with MetS and positively correlated with a number of clinical characteristics of MetS. Interestingly, those genes were not differently expressed in the visceral and subcutaneous adipose tissues between the groups. The authors therefore attributed liver-specific upregulation of genes involved in peripheral cortisol activity and consequent hepatic hypercortisolism to MetS.

Other studies found that the adipose tissue had a higher frequency of genes coding for adipokines than other tissues $(13,64)$. Moreover, visceral adipose tissue had $30 \%$ of these genes whereas the subcutaneous adipose tissue had $20 \%(13,65)$.

One adipokine that highly increases the risk of thrombotic diseases is plasminogen activator inhibitor type 1 (PAI-1). Mertens et al. (66) found a strong correlation between its plasma levels and visceral adiposity. Matzusawa (64) found a tenfold increase in PAI-1 mRNA in animal visceral adipose tissue during fat accumulation while its level in subcutaneous adipose tissue remained unchanged. Funahashi et al. (15), in turn, investigated the genetic reasons underlying the lowering of plasma levels of adiponectin, adipokine that protects against insulin resistance and atherosclerosis, in MetS patients. What lowered adiponectin levels was the missense mutation of the adiponectin gene, with the substitution of isoleucine 164 to threonine in the globular domain. Subjects carrying this mutation were frequently hypertensive, hyperlipidemic, diabetic, and had atherosclerotic vascular diseases.

Studies $(67$, cf. 68) on separated twins and adopted children, designed to compare environmental and genetic influences, showed that obesity was inherited by between $40 \%$ and $70 \%$ of the participants. Ramachandrappa and Farooqi (68) report that by genotyping between 350,000 and 500,000 SNPs covering more than $75 \%$ of the human genome, genome-wide association studies identified more than 20 genetic loci relevant for body weight regulation.

Other researchers $(22,69)$ have reported that maternal diet, growth during early foetal development, and low birth weight are independently associated with the increased risk of MetS in adult life. In a study on nonhuman primates (70), exposure of pregnant mothers (regardless of whether they were lean or obese) to a high-fat diet led to a number of changes in liver metabolism in their offspring that increase the risk of metabolic diseases. The reader may ask how this is related to genetic predisposition. According to Sebert et al. (69), changes in maternal diet or in uterine blood supply near the term can result in cellular stress in the offspring and can modify genes that control DNA methylation. In other words, maternal diet can set off the phenotypes prone to the development of metabolic diseases (69). However, we still do not understand how maternal diet affects DNA modifications and how this interaction triggers the development of metabolic diseases.

\section{Treatment of MetS}

Current therapy of choice for patients diagnosed with MetS is to change their lifestyle by increasing physical activity and improving dietary habits. De Souza Leao et al. (71) compared 15 studies with different approach to the treatment of MetS. Some investigated normocaloric diet alone, some normocaloric diet combined with exercise, some lowcalorie diet combined with exercise, and some lowcalorie diet alone. The best results were obtained with the combination of low-calorie diet and exercise.

Pharmacological treatment of MetS seeks to target a number of specific factors that lead to the disease. On the one hand, this diversity of factors provides many options for drug development, but on the other, diversification encourages partial approach that may not address the complex nature of the disease as efficiently as one hopes for.

One promising specific-target approach is the inhibition of the $11 \beta$-HSD1 enzyme in order to normalise cortisol $(21,22)$. Studies on animals and humans have shown that pharmacological inhibition of $11 \beta$-HSD 1 activity has favourable metabolic (reduction of glucose level, insulin resistance, and dyslipidaemia) and anti-inflammatory effects $(22,23$, 72). A large number of chemical classes have been identified as potent and selective small-molecule 
inhibitors of $11 \beta$-HSD1 $(73,74$, cf. 75). This finding is important since $11 \beta$-HSD 1 could be a valid therapeutic target not only for obesity and MetS, but also for other comorbidities, such as type 2 diabetes $(21,72)$.

Currently, MetS is pharmacologically managed by treating its components: obesity, diabetes, hypertension, and hyperlipidaemia. At the moment, the only registered pharmaceutical for the treatment of obesity through removal of fat tissue, a major component of MetS, is orlistat. Orlistat inhibits pancreatic lipase, and by preventing the hydrolysis of triglyceride esters to free fatty acids and triglyceride, prevents their gastrointestinal absorption (76). Registered antidiabetic drugs include derivates of sulfonylurea, glinides, and acarbose, which all lower blood glucose $(77,78)$. Metformin, a biguanide-type antidiabetic agent, can induce weight loss, and has recently become the first choice in diabetes type 2 treatment in patients with MetS (79). Hypertension, another component of MetS, is treated with anti-hypertensive drugs. There are several groups of antihypertensives that are successfully used in practice, such as diuretics, sympatholitic drugs, vasodilators, and angiotensin-converting enzyme (ACE) inhibitors (80). Some of them, such as ACE inhibitors, central acting antihypertensives, and antagonists of $\alpha 1$-adrenoreceptors, have also shown beneficial effects against insulin resistance (81). Atherogenic dyslipidaemia is usually treated with statins, which target hypercholesterolaemia, and with fibrates or derivatives of nicotinic acid, which target hypertriglyceridaemia (82).

\section{CONCLUSION}

The prevalence of MetS has reached epidemic proportions and the number of patients rises exponentially. Its aetiology is still unclear, but research has identified a number of aetiological and pathophysiological factors and lifestyle triggers. These predisposing factors can be genetic or environmental and persist throughout our life (from foetal development to adult age). Since MetS is associated with diabetes type 2, cardiovascular disease, and certain cancers and significantly diminishes the quality of life and life expectancy, an early recognition and prevention, where possible, is extremely important. Because of known comorbidities of MetS including Cushing's syndrome, PCOS, and depression, treatment should focus on the management of these conditions and improvement of MetS symptoms.

\section{REFERENCES}

1. Grundy SM. Obesity, metabolic syndrome, and cardiovascular disease. J Clin Endocrinol Metab 2004;89:2595-600. doi: 10.1210/jc.2004-0372

2. Blaton VH, Korita I, Bulo A. How is metabolic syndrome related to dyslipidemia? Biochem Medica 2008;18:14-24. doi: 10.11613/BM.2008.003

3. Novelletto BF, Guzzinati S, Avogaro A. Prevalence of metabolic syndrome and its relationship with clinically prevalent cardiovascular disease in the Veneto Region, Northeastern Italy. Metab Syndr Relat Disord 2012;10:56-62. doi: 10.1089/met.2011.0065

4. Jesmin S, Mia MS, Islam AM, Islam MR, Sultana SN, Zaedi S, Yamaguchi N, Okazaki O, Moroi M, Kimura S, Hiroe M. Prevalence of metabolic syndrome among rural Bangladeshi women. Diabetes Res Clin Pract 2012;95:e7-9. doi: 10.1016/ j.diabres.2011.09.025

5. Mattoo SK, Chakraborty K, Basu D, Ghosh A, Vijaya Kumar KG, Kulhara P. Prevalence and correlates of metabolic syndrome in alcohol and opioid dependent inpatients. Indian J Med Res 2011;134:341-8. PMID:21985817

6. Pećin I, Reiner Ž, Jelaković B. Unos soli, metabolički sindrom i pretilost [Salt intake, metabolic syndrome, and obesity, in Croatian]. [displayed 12 May 2012]. Available at http://www. hcjz.hr/old/clanak.php?id=14134

7. Gøbel RJ, Jensen SM, Frøkiaer H, Mølgaard C, Michaelsen KF. Obesity, inflammation and metabolic syndrome in Danish adolescents. Acta Paediatr 2012;101:192-200. doi: 10.1111/ j.1651-2227.2011.02493.x

8. Olza J, Gil-Campos M, Leis R, Bueno G, Aguilera cm, Valle M, Cañete R, Tojo R, Moreno LA, Gil A. Presence of the metabolic syndrome in obese children at prepubertal age. Ann Nutr Metab 2011;58:343-50. doi: 10.1159/000331996

9. World Health Organisation (WHO). Definition, diagnosis and classification of diabetes mellitus and its complications: report of a WHO consultation. Geneva: WHO; 1999.

10. Grundy SM, Cleeman JI, Daniels SR, Donato KA, Eckel RH, Franklin BA, Gordon DJ, Krauss RM, Savage PJ, Smith SC, Jr., Spertus JA, Costa F. Diagnosis and management of the metabolic syndrome: an American Heart Association/National Heart, Lung, and Blood Institute Scientific Statement. Circulation 2005;112:273552. PMID: 16157765

11. Alberti KGMM, Zimmet PZ, Shaw JE; IDF Epidemiology Task Force Consensus Group. The metabolic syndrome: a new world-wide definition from the International Diebetes Federation consensus. Lancet 2005;366:1059-62. doi: 10.1016/S0140-6736(05)67402-8

12. Balkau B, Charles MA. Comment on the provisional report from the WHO consultation. European Group for the Study of Insulin Resistance (EGIR). Diabet Med 1999;16:442-3. PMID: 10342346

13. Matsuzawa Y, Funahashi T, Nakamura T. The concept of metabolic syndrome: contribution of visceral fat accumulation and its molecular mechanism. J Atheroscler Thromb 2011;18:629-39. PMID: 21737960 
14. Isomaa B, Almgren P, Tuomi T, Forsen B, Lahti K, Nissen M, Taskinen M-R, Groop L. Cardiovascular morbidity and mortality associated with the metabolic syndrome. Diabetes Care 2001;24:683-9. doi: 10.2337/diacare.24.4.683

15. Funahashi T, Matsuzawa Y, Kihara S. Adiponectin as a potential key player in metabolic syndrome - insights into atherosclerosis, diabetes and cancer. Int Cong Series 2004;1262:368-71. doi: 10.1016/j.ics.2004.01.091

16. Katzmarzyk PT, Church TS, Janssen I, Ross R, Blair SN. Metabolic syndrome, obesity and mortality: impact of cardiorespiratory fitness. Diabetes care 2005;28:391-7. PMID: 15677798

17. Wilson PW, D'Agostino RB, Parise H, Sullivan L, Meigs JB. Metabolic syndrome as a precursor of cardiovascular disease and type 2 diabetes mellitus. Circulation 2005;112:3066-72. doi: 10.1161/CIRCULATIONAHA.105.539528

18. Duvnjak L, Duvnjak M. The metabolic syndrome - an ongoing story. J Physiol Pharmacol 2009;60(Suppl 7):19-24. PMID: 20388942

19. Rosmond R. Role of stress in the pathogenesis of the metabolic syndrome. Psychoneuroendocrinology 2005;30:110. PMID: 15358437

20. Staab CA, Maser E. 11 $\beta$-Hydroxysteroid dehydrogenase type 1 is an important regulator at the interface of obesity and inflammation. J Steroid Biochem Mol Biol 2010;119: 5672.

21. Wang M. Inhibitors of $11 \beta$-hydroxysteroid dehydrogenase type 1 in antidiabetic therapy. Handb Exp Pharmacol 2011;203:127-46. doi: 10.1007/978-3-642-17214-4 6

22. Anagnostis P, Athyros VG, Tziomalos K, Karagiannis A, Mikhailidis DP. Clinical review: The pathogenetic role of cortisol in the metabolic syndrome: a hypothesis. J Clin Endocrinol Metab 2009;94:2692-701. doi: 10.1210/jc.20090370

23. Morton NM. Obesity and corticosteroids: $11 \beta$-Hydroxysteroid type 1 as a cause and therapeutic target in metabolic disease. Mol Cell Endocrinol 2010;316:154-64. doi: 10.1016/j. mce.2009.09.024

24. Ma X, Lian QQ, Dong Q, Ge RS. Environmental inhibitors of $11 \beta$-hydroxysteroid dehydrogenase type 2 . Toxicology 2011;285:83-9. doi: 10.1016/j.tox.2011.04.007

25. Park SB, Blumenthal JA, Lee SY, Georgiades A. Association of cortisol and the metabolic syndrome in Korean men and women. J Korean Med Sci 2011;26:914-8. doi: 10.3346/ jkms.2011.26.7.914

26. Grossniklaus DA, Gary RA, Higgins MK, Dunbar SB. Biobehavioral and psychological differences between overweight adults with and without waist circumference risk Res Nurs Health 2010;33:539-51. doi: 10.1002/nur.20411

27. Mai K, Reinecke F, Andres J, Bobbert T, Kraatz J, Wudy SA, Hartmann MF, Maser-Gluth C, Pfeiffer AF, Spranger J. Effects of hyperlipidaemia on glucocorticoid metabolism: results of a randomized controlled trial in healthy young women. Clin Endocrinol 2011;74:551-7. doi: 10.1111/j.13652265.2011.03972.x

28. Veldhuis JD, Roelfsema F, Iranmanesh A, Carroll BJ, Keenan DM, Pincus SM. Basal, pulsatile, entropic (patterned), and spiky (staccato-like) properties of ACTH secretion: impact of age, gender, and body mass index. J Clin Endocrinol Metab 2009;94:4045-52. doi: 10.1210/jc.2009-1143

29. Esteghamati A, Morteza A, Khalilzadeh O, Noshad S, Novin L, Nakhjavani M. Association of serum cortisol levels with parameters of metabolic syndrome in men and women. Clin Invest Med 2011;34:E131-7. PMID: 21631989

30. Inder WJ, Obeyesekere VR, Alford FP, Jang C. Skeletal muscle $11 \beta \mathrm{HSD} 1$ activity of nondiabetic subjects is unaltered in central obesity-associated insulin resistance. Horm Metab Res 2011;43:257-60. doi: 10.1055/s-0030-1269905

31. Classen JB. Italian pediatric data support hypothesis that simultaneous epidemics of type 1 diabetes and type 2 diabetes/metabolic syndrome/obesity are polar opposite responses (i.e., symptoms) to a primary inflammatory condition. J Pediatr Endocrinol Metab 2011;24:455-6. PMID: 21932581

32. Björntorp P. Neuroendocrine perturbations as a cause of insulin resistance. Diabetes Metab Res Rev 1999;15:427-41. PMID: 10634968

33. Duvnjak L, Bulum T, Metelko Ž. Hypertension and metabolic syndrome. Diabetol Croat 2008;37:83-9.

34. Landsberg L. Diet, obesity and hypertension: an hypothesis involving insulin, the sympathetic nervous system, and adaptive thermogenesis. Q J Med 1986;61:1081-90. PMID: 3310065

35. Balbo M, Leproult R, Van Cauter E. Impact of sleep and its disturbances on hypothalamo-pituitary-adrenal axis activity. Int J Endocrinol 2010;2010:1-16. doi: $10.1155 / 2010 / 759234$

36. Kohsaka A, Waki H, Cui H, Gouraud SS, Maeda M. Integration of metabolic and cardiovascular diurnal rhythms by circadian clock. Endocr J 2012;59:447-56. PMID: 22361995

37. Laposky AD, Bass J, Kohsaka A, Turek FW. Sleep and circadian rhythms: Key components in the regulation of energy metabolism. FEBS Lett 2008;582:142-51. doi: 10.1016/j.febslet.2007.06.079

38. Scheer FA, Hilton MF, Mantzoros CS, Shea SA. Adverse metabolic and cardiovascular consequences of circadian misalignment. Proc Natl Acad Sci USA 2009;106:4453-8. doi: 10.1073/pnas.0808180106

39. Zvonic S, Floyd ZE, Mynatt RL, Gimble JM. Circadian rhythms and the regulation of metabolic tissue function and energy homeostasis. Obesity 2007;15:539-43. doi: 10.1038/ oby.2007.544

40. Morikawa Y, Nakagawa H, Miura K, Soyama Y, Ishizaki M, Kido T, Naruse Y, Suwazono Y, Nogawa K. Effect of shift work on body mass index and metabolic parameters. Scand J Work Environ Health 2007;33:45-50. doi: 10.5271/ sjweh. 1063

41. Biggi N, Consonni D, Galluzzo V, Sogliani M, Costa G. Metabolic syndrome in permanent night workers. Chronobiol Int 2008;25:443-54. doi: 10.1080/07420520802114193

42. Manenschijn L, van Kruysbergen RG, de Jong FH, Koper JW, van Rossum EF. Shift work at young age is associated with elevated long-term cortisol levels and body mass index. J Clin Endocrinol Metab 2011;96:E1862-5. doi: 10.1210/ jc. 2011-1551

43. Gangwisch JE, Heymsfield SB, Boden-Albala B, Buijs RM, Kreier F, Pickering TG, Rundle AG, Zammit GK, Malaspina D. Short sleep duration as a risk factor for hypertension: analyses of the first National Health and Nutrition Examination Survey. Hypertension 2006;47:833-9. doi: 10.1161/01.HYP.0000217362.34748.e0

44. Vgontzas AN, Lin HM, Papaliaga M, Calhoun S, Vela-Bueno A, Chrousos GP, Bixler EO. Short sleep duration and obesity: 
the role of emotional stress and sleep disturbances. Int J Obes (Lond) 2008;32:801-9. doi: 10.1038/ijo.2008.4

45. Kumari M, Badrick E, Ferrie J, Perski A, Marmot M, Chandola T. Self-reported sleep duration and sleep disturbance are independently associated with cortisol secretion in the Whitehall II study. J Clin Endocrinol Metab 2009;94:4801-9. doi: 10.1210/jc.2009-0555

46. Paslakis G, Gilles M, Lederbogen F, Schilling C, Scharnholz B, Deuschle M. The effect of a 4-week treatment with reboxetine on metabolic parameters of depressed inpatients. Eur Arch Psychiatry Clin Neurosci 2011;261:173-7. doi: 10.1007/s00406-010-0164-4

47. Vogelzangs N, Kritchevsky SB, Beekman ATF, Newman AB, Satterfield S, Simonsick EM, Yaffe K, Harris TB, Penninx BWJH. Depressive symptoms and change in abdominal obesity in older persons. Arch Gen Psychiatry 2008;65:138693. doi: 10.1001/archpsyc.65.12.1386

48. Vogelzangs N, Suthers K, Ferrucci L, Simonsick EM, Ble A, Schrager M, Bandinelli S, Lauretani F, Giannelli SV, Penninx BW. Hypercortisolemic depression is associated with the metabolic syndrome in late-life. Psychoneuroendocrinology 2007;32:151-9. doi: 10.1016/j.psyneuen.2006.11.009

49. Vaccarino V, Bremner DJ. Stress response and the metabolic syndrome. Cardiology/Hospital Physician Cardiology Board Review Manual 2005;11:1-12.

50. Capuron L, Su S, Miller AH, Bremner JD, Goldberg J, Vogt GJ, Maisano C, Jones J, Murrah NV, Vaccarino V. Depressive symptoms and metabolic syndrome: Is inflammation the underlying link? Biol Psychiatry 2008;64:896-900. doi 10.1016/j.biopsych.2008.05.019

51. Vogelzangs N, Duivis HE, Beekman ATF, Kluft C, Neuteboom J, Hoogendijk W, Smit JH, de Jonge P, Penninx BWJH. Association of depressive disorders, depression characteristics and antidepressant medication with inflammation. Transl Psychiatry 2012;2:e79 doi: 10.1038/ tp.2012.8

52. Rege S. Antipsychotic induced weight gain in schizophrenia: mechanisms and management. Aust N Z J Psychiatry 2008;42:369-81. doi: 10.1080/00048670801961123

53. Reynolds GP, Hill MJ, Kirk SL. The 5-HT2C receptor and antipsychoticinduced weight gain - mechanisms and genetics. J Psychopharmacol 2006;20(Suppl 4):15-8. PMID: 16785265

54. Walker EF, Cornblatt BA, Addington J, Cadenhead KS, Cannon TD, McGlashan TH, Perkins DO, Seidman LJ, Tsuang MT, Woods SW, Heinssen R. The relation of antipsychotic and antidepressant medication with baseline symptoms and symptom progression: a naturalistic study of the North American Prodrome Longitudinal Sample. Schizophr Res 2009;115:50-7. doi: 10.1016/j. schres.2009.07.023.

55. Deng C, Weston-Green K, Huang XF. The role of histaminergic $\mathrm{H} 1$ and $\mathrm{H} 3$ receptors in food intake: a mechanism for atypical antipsychotic-induced weight gain? Prog Neuropsychopharmacol Biol Psychiatry 2010;34:1-4. doi: 10.1016/j.pnpbp.2009.11.009

56. van Reedt Dortland AKB, Vreeburg SA, Giltay EJ, Licht cmM, Vogelzangs N, van Veen T, de Geus EJC, Penninx BJWH, Zitman FG. The impact of stress systems and lifestyle on dyslipidemia and obesity in anxiety and depression. Psychoneuroendocrinology 2013;38:209-18. doi: 10.1016/ j.psyneuen.2012.05.017
57. Albrecht U. Timing to perfection: the biology of central and peripheral circadian clocks. Neuron 2012;74:246-60. doi: 10.1016/j.neuron.2012.04.006

58. Kohsaka A, Bass J. A sense of time: how molecular clocks organize metabolism. Trends Endocrinol Metab 2007;18:411. doi: $10.1016 /$ j.tem.2006.11.005

59. Valenzuela FJ, Torres-Farfan C, Richter HG, Mendez N, Campino C, Torrealba F, Valenzuela GJ, Serón-Ferré M. Clock gene expression in adult primate suprachiasmatic nuclei and adrenal: is the adrenal a peripheral clock responsive to melatonin? Endocrinology 2008;149:1454-61. doi: 10.1210/en.2007-1518

60. Gomez-Abellan P, Hernandez-Morante JJ, Lujan JA, Madrid JA, Garaulet M. Clock genes are implicated in the human metabolic syndrome. Int J Obes (Lond) 2008;32:121-8. PMID: 17653067

61. Gomez-Santos C, Gomez-Abellan P, Madrid JA, HernandezMorante JJ, Lujan JA, Ordovas JM Garaulet M. Circadian rhythm of clock genes in human adipose explants. Obesity 2009;17:1481-5. doi: 10.1038/oby.2009.164

62. Gambineri A, Tomassoni F, Munarini A, Stimson RH, Mioni R, Pagotto U, Chapman KE, Andrew R, Mantovani V, Pasquali R, Walker BR. A combination of polymorphisms in HSD11B1 associates with in vivo 11 $\beta$-HSD1 activity and metabolic syndrome in women with and without polycystic ovary syndrome. Eur J Endocrinol 2011;165:283-92. doi: 10.1530/EJE-11-0091

63. Torrecilla E, Fernández-Vázquez G, Vicent D, SánchezFranco F, Barabash A, Cabrerizo L, Sánchez-Pernaute A, Torres AJ, Rubio MA. Liver upregulation of genes involved in cortisol production and action is associated with metabolic syndrome in morbidly obese patients. Obes Surg 2012;22:47886. doi: 10.1007/s11695-011-0524-9

64. Matsuzawa Y. The metabolic syndrome and adipocytokines. FEBS Lett 2006;580:2917-21. doi: 10.1016/j. febslet.2006.04.028

65. Funahashi T, Nakamura T, Shimomura I, Maeda K, Kuriyama H, Takahashi M, Arita Y, Kihara S, Matsuzawa Y. Role of adipocytokines on the pathogenesis of atherosclerosis in visceral obesity. Internal Med 1999;38:202-6. PMID: 10225688

66. Mertens I, Ballaux D, Funahashi T, Matsuzawa Y, Van der Planken M, Verrijken A, Ruige JB, Van Gaal LF. Inverse relationship between plasminogen activator inhibitor-I activity and adiponectin in overweight and obese women. Interrelationship with visceral adipose tissue, insulin resistance, HDL-chol and inflammation. Thromb Haemost 2005;94:1190-5. PMID: 16411393

67. Sorensen TI, Price RA, Stunkard AJ, Schulsinger F. Genetics of obesity in adult adoptees and their biological siblings. BMJ 1989;298:87-90. doi: 10.1136/bmj.298.6666.87

68. Ramachandrappa S, Farooqi IS. Genetic approaches to understanding human obesity. J Clin Invest 2011;121:20806. doi: 10.1172/JCI46044

69. Sebert S, Sharkey D, Budge H, Symonds ME. The early programming of metabolic health: is epigenetic setting the missing link? Am J Clin Nutr 2011;94(Suppl 6):1953S-8S. doi: 10.3945/ajcn.110.001040

70. McCurdy CE, Bishop JM, Williams SM, Grayson BE, Smith MS, Friedman JE, Grove KL. Maternal high-fat diet triggers lipotoxicity in the fetal livers of nonhuman primates. J Clin Invest 2009;119:323-35. doi: 10.1172/JCI32661 
71. de Souza Leao LSC, de Moraes MM, de Carvalho GX, Koifman RJ. Nutritional interventions in Metabolic Syndrome: a systematic review. Arq Bras Cardiol 2011;97:260-5. PMID: 22030698

72. Iovino A, Paquot N, Scheen AJ. Reduction du risque metabolique associe a l'obesite en modulant l'exposition tissulaire au cortisol [Reduction of obesity-related metabolic risk by modulating tissue exposition to cortisol, in French] Rev Med Suisse 2010;6:1608-12. PMID: 20853716

73. Su X, Vicker N, Thomas MP, Pradaux-Caggiano F, Halem H, Culler MD, Potter BV. Discovery of adamantyl heterocyclic ketones as potent $11 \beta$-hydroxysteroid dehydrogenase type 1 inhibitors. ChemMedChem 2011;6:1439-51. doi: 10.1002/ cmdc.201100144

74. Su X, Pradaux-Caggiano F, Vicker N, Thomas MP, Halem $\mathrm{H}$, Culler MD, Potter BV. Adamantyl ethanone pyridyl derivatives: potent and selective inhibitors of human $11 \beta$ hydroxysteroid dehydrogenase type 1 . ChemMedChem 2011;6:1616-29. doi: 10.1002/cmdc.201100182
75. Sun D, Wang M, Wang Z. Small molecule $11 \beta$-hydroxysteroid dehydrogenase type 1 inhibitors. Curr Top Med Chem 2011;11:1464-75. PMID: 21510838

76. Guerciolini R. Mode of action of orlistat. Int J Obes Relat Metab Disord 1997;21(Suppl 3):S12-23. PMID: 9225172

77. Bsataki S. Diabetes mellitus and its treatment. Int J Diabet Metabol 2005;13: 11-34.

78. Francetić I, editor. Farmakoterapijski priručnik [Pharmacotherapy Handbook, in Croatian]. $6^{\text {th }}$ ed. Zagreb: Medicinska naklada; 2010

79. Hundal RS, Inzucchi SE. Metformin: new understandings, new uses. Drugs 2003;63:1879-94. PMID: 12930161

80. Sweetman SC, editor. Martindale: The Complete Drug Reference. $35^{\text {th }}$ ed. London: Pharmaceutical Press; 2006.

81. Opie LH, Schall R. Old antihypertensives and new diabetes. J Hypertens 2004;22:1453-8. PMID: 15257162

82. Law MR, Wald NJ, Rudnicka AR. Quantifying effect of statins on low density lipoprotein cholesterol, ischaemic heart disease, and stroke: systematic review and meta-analysis. BMJ 2003;326:1423. doi: 10.1136/bmj.326.7404.1423 


\section{Sažetak}

\section{ENDOKRINI I GENETIČKI ČIMBENICI TE ŽIVOTNE NAVIKE KOJI PRIDONOSE NASTANKU METABOLIČKOG SINDROMA}

Metabolički sindrom (MetS) kronična je višekomponentna bolest, koju karakteriziraju abdominalna debljina, hiperglikemija, dislipidemija i hipertenzija. Kako MetS dovodi do razvoja šećerne bolesti tipa 2, kardiovaskularnih i nekih malignih bolesti te posljedično do prerane smrti, ne čudi da MetS privlači pozornost znanstvenika diljem svijeta. Etiopatologija MetSa je kompleksna te još nije u potpunosti razjašnjena. Cilj je ovoga rada dati literaturni pregled uloge nekih endokrinih poremećaja, kao što su poremećaj kortizola i inzulina, u razvoju MetSa. Također, razmatrani su i neki faktori načina života/životnog stila te genetički faktori koji pridonose razvoju MetSa. Na kraju su spomenuta trenutačna saznanja u liječenju MetSa i njegovih komponenti.

KLJUČNE RIJEČI: cirkadijalni ritam, hiperglikemija, hipertenzija, inzulin, kardiovaskularne bolesti, kortizol, MetS, šećerna bolest

\section{CORRESPONDING AUTHOR:}

Ana-Marija Domijan

Faculty of Pharmacy and Biochemistry,

University of Zagreb

A. Kovačića 1, 10000 Zagreb, Croatia

E-mail:adomijan@pharma.hr 